\title{
Pengaruh Penambahan Probio dalam Pakan terhadap Bobot Hidup, Berat Karkas, Berat Dada, Berat Paha Atas dan Paha Bawah Ayam Broiler
}

Alexander Taek Nahak ${ }^{\mathrm{a}}$

${ }^{a}$ Fakultas Pertanian, Universitas Timor, Kefamenanu, TTU - NTT, Indonesia, email: nahaksander@ gmail.com

\section{Article Info}

\section{Article history:}

Received 12 Juli 2018

Received in revised form 13 November 2018 Accepted 2 Februari 2019

DOI:

https://doi.org/10.32938/ja.v4i2.201

Keywords :

Ayam Broiler

Bobot Hidup

Berat Karkas

Berat Dada

Berat Komersial Karkas

\section{Abstrak}

Tujuan dari penelitian ini adalah untuk mengetahui pengaruh penambahan probio dalam pakan terhadap bobot hidup, berat karkas, berat dada, berat paha atas, dan paha bawah ayam broiler. Dalam penelitian ini digunakan 80 ekor ayam broiler umur sehari (DOC). Metode yang digunakan adalah metode experimen dengan Rancangan Acak Lengkap (RAL) menggunakan 4 perlakuan dan 4 ulangan. Perlakuannya terdiri dari $\mathrm{R}_{0}=100 \%$ pakan komersial, $\mathrm{R}_{1}=99,7 \%$ pakan komersial + probio $0,3 \%, \mathrm{P}_{2}=99,5 \%$ pakan komersial + probio $0,5 \%$ dan $\mathrm{R}_{3}=99,3 \%$ pakan komersial + probio $0,7 \%$. Hasil analisis sidik ragam menunjukkan bahwa penggunaan probio dalam pakan komersial berpengaruh tidak nyata terhadap bobot hidup, berat dada, berat paha atas dan paha bawah ayam broiler namun berpengaruh nyata terhadap berat karkas $(\mathrm{P}<0,05)$. Kesimpulan dari hasil penelitian ini adalah penambahan probio dalam pakan sampai level $0,3 \%$ meningkatkan berat karkas ayam broiler tetapi tidak mempengaruhi bobot hidup, persentase karkas, berat dan persentase berat dada, persentase berat paha, paha atas dan paha bawah ayam broiler pada umur 45 hari.

\section{Pendahuluan}

Usaha ayam pedaging di Pulau Timor khususnya Kabupaten Timor Tengah Utara (TTU) mengalami perkembangan yang semakin meningkat karena adanya kesadaran masyarakat akan pentingnya nilai gizi yang bersumber dari protein hewan serta pendapatan yang dapat memenuhi kebutuhan keluarga. Ketertarikan usaha in dipegaruhi oleh beberapa faktor seperti masa panen yang relatif cepat dan pemeliharaan yang tidak terlalu sulit. Selain itu ayam, broiler memiliki pertumbuhan cepat, bobot badan besar dengan persentase daging dada dan paha yang tingg sehingga berpengaruh pada tingginya permintaan. Salah satu faktor yang mempengaruhi produktivitas ternak ayam broiler dengan biaya yang harus dikeluarkan cukup besar adalah faktor pakan. Pakan dengan komposisi nutrien yang lengkap menyebabkan kecernaan lebih baik dan absorbsi nutrien lebih maksimal Pencernaan dan absorbsi nutrient tidak hanya dipengaruhi oleh kualitas pakan tetap juga oleh kondisi saluran pencernaan terutama usus. Pemanfaatan nutrient pakan hanya dapat tercapai secara optimal jika saluran pencernaan dalam keadaan normal atau sehat. Di dalam saluran pencernaan terdapat banyak mikroba patogen yang bersifat negatif dan merugikan. Mikroba patogen di dalam usus, menempel pada dinding-dinding usus terutama vili-vili usus sehingga menghalangi proses pencernaan, gerakan peristaltik usus dan absorbsi nutrien. Akibat selanjutnya, pakan yang dikonsumsi tidak maksimal dicerna oleh usus (proses enzimatik) dan nutrient banyak yang terbuang bersama ekskreta. Untuk mengoptimalkan kegunaan saluran pencernaan (usus) maka dapat dibantu dengan penambahan probiotik (bakteri positif atau bakteri non-patogen) Probiotik diartikan sebagai kultur tunggal atau campuran dari bakteri hidup yang dapat diaplikasikan kepada hewan maupun manusia, dan dapat memberikan keuntungan bagi inangnya dalam meningkatkan kinerja mikroflora alami tubuh (Manin, 2010). Penambahan probiotik dapat menghalangi dan meminimalkan kerja bakteri negatif dalam usus tersebut. Probiotik dapa digunakan sebagai bahan pakan tambahan yang bertujuan untuk memperbaiki pencernaan dan mempercepat pertumbuhan ayam broiler. Probiotik dilaporkan dapat mengubah pergerakan mucin dan populasi mikroba di dalam usus ayam, sehingga keberadaannya dapat meningkatkan fungsi dan kesehatan usus, meningkatkan penyerapan zat-zat makanan, serta memperbaiki komposisi mikroflora (Mountzouris et al., 2010). Fungsi dari probiotik adalah meningkatkan efisiens ransum, produksi telur, dan menurunkan kadar kolesterol telur serta kolestero serum, dan probiotik juga mampu menurunkan nitrogen non protein dalam darah, konsentrasi asam urat, amonia dan urea dalam darah (Isshiki, 1979). Suplementasi probiotik dalam pakan dapat meningkatkan berat karkas dan persentase daging karkas serta dapat menurunkan jumlah lemak subkutan (Ramia, 2000). Diharapkan dengan penambahan probiotik dalam pakan dapat meminimalisir biaya pakan yang dikeluarkan peternak.

Produktivitas ternak ayam broiler dapat dilihat dari bobot hidup dan berat karkas termasuk didalmnya berat dada, berat paha atas dan paha bawah ayam broiler. Bobot hidup adalah bobot ayam yang ditimbang sebelum dipotong setelah ayam dipuasakan selama 8 jam (Soeparno, 1994). Bobot hidup bisa diketahui dengan cara penimbangan ayam hidup. Bobot hidup yang tingg menggambarkan karkas yang baik serta perdagingan yang banyak. Bobot hidup yang tinggi dipengaruhi oleh kualitas dan kuantitas ransum yang dikonsumsi, dan faktor lingkungan lainnya (Blakely dan Bade, 1991). Karkas merupakan hasil utama pemotongan ternak yang memiliki nilai ekonomis tinggi (Soeparno, 1994). Karkas ayam broiler adalah daging bersama tulang hasil pemotongan, tanpa darah, setelah dipisahkan dari kepala sampai batas pangkal leher dan dari kaki sampai batas lutut serta isi rongga perut ayam. Karkas adalah bagian tubuh ayam tanpa bulu, darah, leher, kaki bagian bawah (cakar), dan jeroan (Haroen, 2003). Pencapaian bobot karkas sangat berkaitan dengan bobot hidup dan pertambahan bobot badan (Haroen, 2003). Bagian dada terdiri dari sternum dan otot yang terkait. Sternum bisa dalam bentuk utuh (dada penuh) atau dibelah menjadi dua bagian yaitu bagian kanan dan kiri (Soeparno, 1994). Pada permukaan dada terdapat otot yang besar disebut dengan otot pectoralis. Oto pectoralis berlokasi di bagian sternum pada dada depan (brisket) dan meluas ke bagian dada belakang. Paha terdiri dari otot besar dan pada umumnya menghasilkan daging dengan keempukan yang sedang sampai empuk serta harga yang mahal. Paha (leg) dipisahkan pada bagian ace tubulum, otot pelvik diikutkan, sedangkan tulang pelvik tidak diikutkan pada paha (Soeparno, 1994). Penelitian ini bertujuan untuk mengetahui pengaruh penambahan probio dalam ransum terhadap pertambahan bobot potong, berat karkas, berat dada, berat paha atas dan paha bawah ayam broiler.

\section{Metode}

\subsection{Waktu dan lokasi penelitian}

Penelitian ini dilaksanakan di kandang ayam broiler milik Program Studi Peternakan, Fakultas Pertanian, Universitas Timor, Kelurahan Sasi Kecamatan Kota Kefamenanu Kabupaten Timor Tengah Utara (TTU). Penelitian ini berlangsung selama 1 periode produksi (45 hari)

\subsection{Alat dan bahan}

Materi penelitian yang digunakan adalah ayam broiler berjumlah 80 ekor, bahan pakan komersial BR1, BR2 dan probiotik. Sedangkan peralatan yang digunakan adalah tempat makan, tempat minum, pemanas (lampu), alat tulis, ember, gayung, bokor, koran tali rafia, isolasi dan timbangan duduk merek Ohaus kapasitas $5 \mathrm{~kg}$ dengan tingkat kepekaan 1 gram serta alat pemotongan ternak.

\subsection{Rancangan Percobaan}

Metode yang digunakan dalam penelitian ini adalah metode experimen dengan menggunakan Rancangan Acak Lengkap (RAL) yang terdiri dari 4 perlakuan dan 4 ulangan sehingga terdapat 16 unit percobaan. Setiap unit percobaan terdapat 5 ekor broiler sehingga total ayam broiler yang digunakan dalam perlakuan 80 ekor. Penempatan anak ayam broiler dilakukan secara acak. Perlakuan yang diberikan adalah:

$\mathrm{R}_{0}: 100 \%$ Pakan komersial tanpa Probiotik

$\mathrm{R}_{1}: 99,7 \%$ pakan komersial $+0,3 \%$ probiotik

$\mathrm{R}_{2}: 99,5 \%$ pakan komersial $+0,5 \%$ probiotik

$\mathrm{R}_{3}: 99,3 \%$ pakan komersial $+0,7 \%$ probiotik

\subsection{Prosedur penelitian}

Persiapan kandang dilakukan dengan cara seluruh ruang kandang dicucihamakan dengan antiseptik (neo antisep) seminggu sebelum penelitian. Peralatan makan dan minum dibersihkan dan dicucihamakan dengan neo antisep. Persiapan bahan kandang seperti alas kandang (sekam dan kapur) Setelah DOC tiba tindakan selanjutnya adalah: DOC diistrahatkan kurang lebih $1 / 2$ jam, pemberian air gula, pemberian pakan awal yang di berikan di tempat makan yang telah disiapkan. Pemberian air minum dicampur vitamin. Pada umur 3 hari dilakukan vaksinasi $\mathrm{ND}_{1}$ melalui tetes mata. Pemberian pakan dan air minum yang di campur vitamin sampai ayam berumur 10 hari. Pada umu 10 hari penempatan ayam di dalam kandang di lakukan secara acak sesuai perlakun. Adaptasi pakan sesuai perlakuan pada hari ke 11 sampai 14 Pemberian perlakuan pada hari pertama sampai panen kemudian pada umur 21 hari di berikan vaksin $\mathrm{ND}_{2}$ (Lasota), serta pengambilan data setelah periode terakhir (panen).

\subsection{Variabel penelitian}

Variabel yang diukur dalam penelitian yaitu bobot hidup, berat dan persentase karkas, berat dan persentase dada, berat dan persentase paha atas dan paha bawah

\subsection{Analisis data}

Data yang diperoleh dalam penelitian ini dianalisis menggunakan analisis sidik ragam (Anova) sesuai dengan Rancangan Acak Lengkap (RAL) dan dilanjutkan dengan uji jarak berganda Duncan (Duncan's New Multiple Range Test) (Stell and Torrie, 1995). 


\section{Hasil dan Pembahasan}

\subsection{Pengaruh Perlakuan Terhadap Bobot Hidup Ayam Broiler}

Bobot hidup ayam broiler sangat dipengaruhi oleh beberapa hal seperti pakan, pertambahan berat badan dan lainnya. Rata-rata bobot hidup ayam broiler yang diberi pakan dengan penambahan probiotik dalam dilihat pada Tabel 1.

Tabel 1. Rata-rata bobot hidup ayam broiler (g/ekor)

\begin{tabular}{|c|c|c|c|c|c|}
\hline \multirow{2}{*}{ Ulangan } & \multicolumn{4}{|c|}{ Perlakuan } & \multirow{2}{*}{ Jumlah } \\
\hline & $\mathrm{R}_{0}$ & $\mathrm{R}_{1}$ & $\mathrm{R}_{2}$ & $\mathrm{R}_{3}$ & \\
\hline 1 & $1.930,00$ & $2.092,00$ & $1.801,00$ & $1.664,00$ & \\
\hline 2 & $1.717,00$ & $1.867,00$ & $1.886,00$ & $1.834,00$ & \\
\hline 3 & $1.897,00$ & $1.767,00$ & $1.805,00$ & $1.889,00$ & \\
\hline 4 & $1.702,00$ & $2.162,00$ & $1.751,00$ & $1.626,00$ & \\
\hline Jumlah & $7.246,00$ & $7.888,00$ & $7.243,00$ & $7.013,00$ & $29.390,00$ \\
\hline Rata-rata & $1.811,50$ & $1.972,00$ & $1.810,75$ & $1.753,25$ & $1.840,63$ \\
\hline
\end{tabular}

Pada Tabel 1 terlihat bahwa rata-rata bobot hidup tertinggi pada perlakuan $\mathrm{R}_{1}$ (1972,00 g/ekor), diikuti perlakuaan $\mathrm{R}_{0}$ (1811,50 g/ekor ), $\mathrm{R}_{2}$ (1810,75 g/ekor) dan terendah $\mathrm{R}_{3}(1753,25 \mathrm{~g}$ /ekor). Hasil analisis sidik ragam menunjukkan bahwa perlakuan berpengaruh tidak nyata terhadap bobot hidup ayam broiler. Hal ini menunjukkan bahwa secara umum nilai rataan bobot hidup pada perlakuan $\mathrm{R}_{0}, \mathrm{R}_{1}, \mathrm{R}_{2}$, dan $\mathrm{R}_{3}$ memberikan kontribusi yang sama terhadap bobot hidup pada setiap perlakuan. Secara statistik probiotik tidak berpengaruh nyata pada bobot hidup namun dilihat dari setiap perlakuan $P_{1}$ (1972,00 g/ekor), cenderung lebih baik dari perlakuan lainnya. Hal ini disebabkan karena level pemberian probiotik $0,3 \%+99,7 \%$ pakan komersial meningkatkan berat hidup. Hasil ini sesuai dengan penelitian yang dilakukan oleh Ronstarci et al. (2007), bahwa penggunaan probiotik (Cellulomonas sp.) dalam pakan memberikan pengaruh tidak nyata terhadap persentase karkas dengan dosis $0,1-1,6 \mathrm{ml} / \mathrm{kg}$ pakan. Pemberian probiotik dalam bentuk cair maupun padat sama-sama tidak memberikan pengaruh yang nyata terhadap persentase karkas. Pengaruh yang tidak nyata pada pemberian probiotik terhadap bobot hidup disebabkan oleh strain tunggal (Enterococcus faecalis) yang digunakan, mikroba tersebut kurang optimal dalam meningkatkan bobot hidup, hal ini dibuktikan dengan hasil penelitian yang dilakukan oleh Daud (2006), menggunakan multi strain dengan kombinasi Bacillus sp.dan Lactobacillus spp yang secara signifikan dapat meningkatkan bobot hidup broiler. Penggunaan multi strain lebih efektif dalam meningkatkan bobot hidup ayam broiler.

\subsection{Pengaruh Perlakuan Terhadap Berat dan Persentase Karkas Ayam} Broiler

Berat karkas adalah berat ayam yang dipotong dan dipisahkan dari darah, kepala, leher, kaki dan organ dalam sedangkan persentase karkas adalah berat karkas dibagi berat hidup dikali $100 \%$. Rata-rata berat karkas dan persentase karkas terlihat pada Tabel 2 dan Tabel 3.

Tabel 2. Rata-rata berat karkas ayam broiler (g/ekor)

\begin{tabular}{|c|c|c|c|c|c|}
\hline \multirow{2}{*}{ Ulangan } & \multicolumn{4}{|c|}{ Perlakuan } & \multirow{2}{*}{ Jumlah } \\
\hline & $\mathrm{R}_{0}$ & $\mathrm{R}_{1}$ & $\mathrm{R}_{2}$ & $\mathrm{R}_{3}$ & \\
\hline 1 & $1.321,85$ & $1.393,66$ & $1.232,60$ & $1.090,53$ & \\
\hline 2 & $1.170,96$ & $1.319,49$ & $1.258,07$ & $1.217,83$ & \\
\hline 3 & $1.230,46$ & $1.262,71$ & $1.242,24$ & $1.317,22$ & \\
\hline 4 & $1.097,74$ & $1.499,37$ & $1.181,61$ & $1.080,33$ & \\
\hline Jumlah & $4.821,01$ & $5.475,23$ & $4.914,52$ & $4.705,91$ & $19.916,67$ \\
\hline Rataan & $1.282,50^{\mathrm{ab}}$ & $1.368,81^{\mathrm{a}}$ & $1.228,63^{\mathrm{ab}}$ & $1.176,48^{\mathrm{b}}$ & $1.244,79$ \\
\hline
\end{tabular}

Terlihat bahwa rata-rata berat karkas tertinggi pada perlakuan $R_{1}$ (1368,81 kg/ekor), diikuti perlakuaan $\mathrm{R}_{0}$ (1282,50 kg/ekor), $\mathrm{R}_{2} \quad(1228,63$ $\mathrm{kg} /$ ekor) dan terendah $\mathrm{R}_{3}(1176,48 \mathrm{~kg} /$ ekor). Hasil Analisis Sidik Ragam menunjukkan bahwa perlakuan berpengaruh nyata $(\mathrm{P}<0,05)$ terhadap berat karkas ayam broiler. Hal ini menunjukkan bahwa penambahan probiotik dalam pakan $0,3 \%$ memberikan pengaruh terhadap berat karkas ayam broiler. Apabila ditingkatkan menjadi $0,5 \%$ dan $0,7 \%$ probio dalam pakan, menyebabkan penurunan berat karkas. Hal ini mengindikasikan bahwa penambahan probiotik dalam pakan BRI dan BR2 batasannya sampai 0,30\%. Pada umumnya persentase karkas dipengaruhi oleh bobot potong, bobot karkas dan lemak abdominal (Rasyaf, 1994).

Tabel 3. Rata-rata persentase berat karkas ayam broiler (\%)

\begin{tabular}{cccccc}
\hline \multirow{2}{*}{ Ulangan } & \multicolumn{5}{c}{ Perlakuan } \\
\cline { 2 - 5 } & $\mathrm{R}_{0}$ & $\mathrm{R}_{1}$ & $\mathrm{R}_{2}$ & $\mathrm{R}_{3}$ & Jumlah \\
\hline 1 & 68,48 & 66,62 & 68,43 & 65,54 & \\
2 & 68,28 & 70,67 & 66,70 & 66,40 & \\
3 & 64,86 & 69,95 & 68,82 & 69,73 & \\
4 & 64,49 & 69,35 & 67,48 & 66,44 & \\
Jumlah & 266,04 & 278,10 & 271,4 & 268,11 & $1.083,71$ \\
Rataan & 66,51 & 69,52 & 67,86 & 67,02 & 67,73 \\
\hline
\end{tabular}

Persentase karkas tertinggi pada $\mathrm{R}_{1}(69,52 \%)$ diikuti $\mathrm{R}_{2}(67,86 \%), \mathrm{R}_{3}$ $(67,02 \%)$ dan terendah $\mathrm{R}_{0}(66,51 \%)$. Hasil analisis sidik ragam menunjukkan bahwa perlakuan berpengaruh tidak nyata terhadap persentase karkas. Persentase karkas erat hubungannya dengan bobot hidup ternak, semakin besar bobot hidup ternak maka produksi karkas semakin tinggi. Walaupun analisis statistik menunjukkan tidak ada perbedaan diantara perlakuan namun secara numerik perlakuan $R_{1}$ dengan penambahan probiotik sebanyak $0,30 \%$ dalam pakan menghasilkan persentase tertinggi. Hasil penelitian ini berhubungan dengan bobot karkas yang tertinggi pada $R_{1}$. Persentase karkas dapat dipengaruhi bobot badan, bangsa ternak, jenis kelamin, organ dalam, dan mutu ransum (Rizal, 2006). Murtidjo (1987) menyatakan bahwa persentase karkas merupakan faktor yang paling untuk menilai produksi ternak, karena produksi erat hubungannya dengan bobot hidup.Semakin bertambah bobot hidupnya maka produksi karkasnya semakin meningkat. Ayam yang bobot tubuhnya tinggi akan menghasilkan persentase karkas yang tinggi, sebaliknya ayam yang bobot hidupnya rendah akan menghasilkan persentase karkas yang rendah.

\subsection{Pengaruh Perlakuan Terhadap Berat dan Persentase Berat Dada Ayam Broiler}

Rata-rata berat dada dan persentase berat dada ayam broiler hasil penelitian disajikan pada Tabel 4 dan 5 . Rata-rata berat dada tertinggi pada $R_{1}$ (557,62 g/ekor) diikuti perlakuan $\mathrm{R}_{0}\left(505,59\right.$ g/ekor), $\mathrm{R}_{2}$ (480,31 g/ekor) dan terendah pada perlakuan $\mathrm{R}_{3}(462,27 \mathrm{~g} / \mathrm{ekor})$. Rata-rata persentase berat dada tertinggi pada $\mathrm{R}_{1}(28,37 \%)$ diikuti perlakuan $\mathrm{R}_{0}(27,70 \%), \mathrm{R}_{2}(26,54 \%)$ dan nilai terendah pada perlakuan $\mathrm{R}_{3}(26,29 \%)$. Hasil Analisis Sidik Ragam menunjukkan bahwa perlakuaan berpengaruh tidak nyata terhadap berat dada maupun persentase berat dada ayam broiler. Penambahan probiotik dalam pakan sampai level $0,7 \%$ tidak berpengaruh terhadap berat dada dan persentase berat dada ayam broiler.

$\underline{\text { Tabel 4. Rata-rata berat dada ayam broiler (g/ekor) }}$

\begin{tabular}{cccccc}
\hline \multirow{2}{*}{ Ulangan } & \multicolumn{4}{c}{ Perlakuan } & \multirow{2}{*}{ Jumlah } \\
\cline { 2 - 5 } & $\mathrm{R}_{0}$ & $\mathrm{R}_{1}$ & $\mathrm{R}_{2}$ & $\mathrm{R}_{3}$ & \\
\hline 1 & 578,23 & 546,50 & 477,56 & 429,14 & \\
3 & 449,27 & 572,41 & 469,14 & 466,35 & \\
4 & 481,83 & 511,24 & 512,27 & 547,44 & \\
Jumlah & 513,01 & 600,31 & 462,27 & 406,13 & \\
Rataan & 2022,34 & 2230,46 & 1921,24 & 1849,06 & 8023,10 \\
\hline
\end{tabular}

Tabel 5. Rata-rata persentase berat dada ayam broiler (\%)

\begin{tabular}{cccccc}
\hline \multirow{2}{*}{ Ulangan } & \multicolumn{4}{c}{ Perlakuan } & \multirow{2}{*}{ Jumlah } \\
\cline { 2 - 5 } & $\mathrm{R}_{0}$ & $\mathrm{R}_{1}$ & $\mathrm{R}_{2}$ & $\mathrm{R}_{3}$ & \\
\hline 1 & 29,96 & 26,12 & 26,52 & 25,79 & \\
2 & 25,28 & 30,66 & 24,87 & 25,43 & \\
3 & 25,40 & 28,93 & 28,38 & 28,98 & \\
4 & 30,14 & 27,77 & 26,40 & 24,98 & \\
Jumlah & 110,78 & 113,48 & 106,17 & 105,17 & 435,61 \\
Rataan & $27,70^{\mathrm{ab}}$ & $28,37^{\mathrm{a}}$ & $26,54^{\mathrm{ab}}$ & $26,29^{\mathrm{b}}$ & 27,23 \\
\hline
\end{tabular}

Penambahan probiotik dalam pakan berpengaruh tidak nyata terhadap berat dada dan persentase berat dada ayam broiler, hal ini dapat disebabkan oleh kondisi saluran pencernaan yang sama sehingga proses pencernaan dan penyerapan nutrien untuk semua perlakuan relatif sama. Pada Tabel 1, Tabel 2 dan Tabel 3, pengaruh perlakuan juga tidak nyata terhadap berat hidup maupun persentase karkas. Akibatnya pada berat dan persentase berat dada juga berbeda tidak nyata. Otot dada yang baik dan besar akan meningkatkam berat karkas. Dari penelitian ini berat karkas tertinggi pada perlakuan $\mathrm{R}_{1}$ dengan demikian berat dada juga lebih tinggi.

\subsection{Pengaruh Perlakuan Terhadap Persentase Berat paha, Paha Atas} dan Paha BawahAyam Broiler

Persentase berat paha diperoleh dengan cara berat paha dibagi berat hidup dikali $100 \%$. Berat paha atas dan paha bawah diperoleh dengan cara memisahkan paha dari bagian karkas lainnya kemudian pemisahan paha atas dan bawah pada persendian tulang tibia dan tulang metatarsal. Rata-rata persentase berat paha, berat paha atas dan paha bawah ayam broiler terlihat pada Tabel 6, Tabel 7 dan Tabel 8.

$\underline{\text { Tabel 6. Rata-rata berat paha atas ayam broiler (g/ekor) }}$

\begin{tabular}{cccccc}
\hline \multirow{2}{*}{ Ulangan } & \multicolumn{4}{c}{ Perlakuan } & \multirow{2}{*}{ Jumlah } \\
\cline { 2 - 5 } & $\mathrm{R}_{0}$ & $\mathrm{R}_{1}$ & $\mathrm{R}_{2}$ & $\mathrm{R}_{3}$ & \\
\hline 1 & 199,07 & 223,36 & 210,73 & 193,46 & \\
2 & 272,37 & 213,68 & 233,44 & 222,97 & \\
3 & 225,99 & 248,53 & 194,91 & 220,52 & \\
4 & 205,30 & 282,77 & 201,23 & 188,36 & \\
Jumlah & 902,73 & 968,34 & 840,31 & 825,31 & $3.536,69$ \\
Rataan & 225,68 & 242,08 & 210,07 & 206,32 & 221,04 \\
\hline
\end{tabular}

Rata-rata persentase berat paha tertinggi pada $\mathrm{R}_{0}(21,90 \%)$ diikuti perlakuan $\mathrm{R}_{1}(21,82 \%), \mathrm{R} 2(21,15 \%)$ dan terendah pada perlakuan $\mathrm{R}_{3}$ $(21,06 \%)$. Rata-rata berat paha atas tertinggi pada $\mathrm{R}_{1}(242,08$ g/ekor), diikuti 
perlakuan $\mathrm{R}_{0}$ (225,68 g/ekor), $\mathrm{R}_{2}$ (210,07 g/ekor) dan terendah pada perlakuan $\mathrm{R}_{3}$ (206,32 g/ekor). Rata-rata berat paha bawah tertinggi pada perlakuan $\mathrm{R}_{1}$ (187,73 g/ekor), diikuti perlakuan $\mathrm{R}_{0}(173,78 \mathrm{~g} / \mathrm{ekor}), \mathrm{R}_{2}$ (173,20 g/ekor) dan terendah pada perlakuan $\mathrm{R}_{3}(163,56 \mathrm{~g} / \mathrm{ekor})$.

Tabel 7. Rata-rataberat paha bawah ayam broiler (g/ekor)

\begin{tabular}{cccccc}
\hline \multirow{2}{*}{ Ulangan } & \multicolumn{4}{c}{ Perlakuan } & \multirow{2}{*}{ Jumlah } \\
\cline { 2 - 5 } & $\mathrm{R}_{0}$ & $\mathrm{R}_{1}$ & $\mathrm{R}_{2}$ & $\mathrm{R}_{3}$ & \\
\hline 1 & 190,07 & 206,86 & 176,86 & 150,72 & \\
2 & 175,21 & 180,11 & 188,20 & 164,32 & \\
3 & 179,05 & 159,70 & 160,88 & 192,00 & \\
4 & 150,79 & 204,26 & 166,89 & 147,20 & \\
Jumlah & 695,12 & 750,93 & 692,83 & 654,24 & $2.793,12$ \\
Rataan & 173,78 & 187,73 & 173,20 & 163,56 & 174,57 \\
\hline
\end{tabular}

Tabel 8. Rata-rata persentase berat paha ayam broiler $(\%)$

\begin{tabular}{cccccc}
\hline \multirow{2}{*}{ Ulangan } & \multicolumn{5}{c}{ Perlakuan } \\
\cline { 2 - 5 } & $\mathrm{R}_{0}$ & $\mathrm{R}_{1}$ & $\mathrm{R}_{2}$ & $\mathrm{R}_{3}$ & Jumlah \\
\hline 1 & 20,16 & 20,56 & 21,52 & 20,68 & \\
2 & 25,18 & 21,09 & 22,35 & 21,11 & \\
3 & 21,35 & 23,10 & 19,71 & 21,83 & \\
4 & 20,92 & 22,52 & 21,02 & 20,63 & \\
Jumlah & 87,62 & 87,28 & 84,61 & 84,27 & 343,79 \\
Rataan & 21,90 & 21,82 & 21,15 & 21,07 & 21,48 \\
\hline
\end{tabular}

Hasil Analisis Sidik Ragam menunjukkan bahwa perlakuaan berpengaruh tidak nyata terhadap persentase berat paha, berat paha atas dan berat paha bawah ayam broiler. Penambahan probiotik dalam pakan sampai level $0,7 \%$ tidak berpengaruh terhadap berat paha ayam broiler. Berat dan persentase berat dada berhubungan dengan karkas dan berat hidup ayam. Walaupun perlakuan berpengaruh tidak nyata namun secara numerik perlakuan $\mathrm{R}_{2}$ paling tinggi dalam menghasilkan berat dan persentase paha. Pada Tabel 1 , Tabel 2 dan Tabel 3 terlihat bahwa berat hidup maupun berat karkas berpengaruh tidak nyata. Akibatnya berat paha dan persentasenya yang merupakan bagian dari karkas juga berbeda tidak nyata.Berat potongan komersial karkas bagian paha atas dan bawah cenderung meningkat seiring dengan meningkatknya level probiotik yang diberikan, namun secara statistik berbeda tidak nyata. Hal ini disebabkan oleh berat karkas yang semakin meningkat sehingga bagian karkas seperti berat paha atas dan paha bawah juga ikut meningkat. Selain itu berat paha juga erat hubungannya dengan berat tulang yang meningkat. Soeparno (1994) yang menyatakan bahwa selama pertumbuhan, tulang tumbuh secara terus-menerus dengan kadar laju pertumbuhan relatif lambat, sedangkan pertumbuhan otot relatif lebih cepat sehingga rasio otot dengan tulang meningkat selama pertumbuhan dengan kadar laju yang berbeda.

\section{Simpulan}

Disimpulkan bahwa penambahan probiotik dalam pakan pada level $0,3 \%$ meningkatkan berat karkas ayam broiler tetapi tidak berpengaruh pada bobot hidup, persentase karkas, berat dan persentase berat dada, persentase berat paha, berat paha atas dan paha bawah ayam broiler pada umur 45 hari.

Pustaka

Blakely, J. and David H. B. 1991. The Science of Animal Hubandry. PrinticeHall Inc. New Jersey.

Daud, M. 2006. Persentase dan kualitas Ayam Pedaging yang diberi Probiotik dan Prebiotik dalam Ransum. Jurnal Ilmu Ternak, 6 (2) : 126-131.

Haroen,U. 2003. Respon ayam broiler yang diberi tepung daun sengon (Abizzania falcataria) dalam ransum terhadap pertumbuhan dan hasil karkas. Jurnal Ilmiah Ilmu-ilmu Peternakan, 6 (1) : 34-41.

Isshiki, Y. 1979. Effect of lactobacili in the diet on the concentration of nitrogenus chikens. Japanese Poultry Sci, 16 (5) :254-258.

Manin, F. 2010. Potensi Lactobacillus acidophilusdan Lactobacillusfermentum dari Saluran Pencernaan Ayam Buras Asal Lahan Gambut sebagai Sumber Probiotik. Jurnal Ilmiah Ilmu-Ilmu Peternakan, 13 (5) : 221 228.

Mountzouris K.C., P. Tsitrsikos, I. Palamidi, A. Arvaniti, M. Mohnl, G. Schatzmayr and K. Fegeros. 2010. Effects of probiotic inclusion levels in broiler nutrition on growth performance, nutrient digestibility, plasma immunoglobulins and cecal microflora composition. Poult. Sci, 89 (1) : 5867.

Murtidjo, B. A. 1987. Pedoman Meramu Pakan Unggas. Kanisius. Yagyakarta.

Ramia, I.K. 2000. Suplementasi Probiotik dalam Ransum Berprotein Rendah terhadap Penampilan Itik Bali. Majalah Ilmiah Peternakan. Fakultas Peternakan Universitas Udayana, Denpasar: 45-54.

Rasyaf,M. 1994. Makanan Ayam Broiler. Yayasan Kanisius, Yogyakarta.

Rizal, Y. 2006. Ilmu Nutrisi Unggas. Padang : Andalas University Press.

Ronstarci, T., Osfar, S. dan Irfan, H. D. 2007. Pengaruh Penambahan Probiotik Selulolitik (Cellulomonas Sp.) dalam Pakan Terhadap Kualitas Karkas, Lemak Abdominal dan Berat Organ dalam Ayam Pedaging. S2 Thesis. Universitas Brawijaya, Malang.
Soeparno, 1994. Ilmu Teknologi Daging. Gadjah Mada University Press, Yogyakarta.

Steel, C.J. dan J.H. Torrie.1995. Prinsip dan Prosedur Statistik. PT. Gramedia. Jakarta. 